\title{
The Relationship of Servant Leadership with Trust and Organizational Efficacy
}

\author{
Naser Nastiezaie ${ }^{1}$, Mosayeb Bameri ${ }^{2} \&$ Nemat Allah Rahimi Dadkan ${ }^{2}$ \\ ${ }^{1}$ Assistant professor of educational administration, University of Sistan and Baluchestan, Zahedan, Iran \\ ${ }^{2}$ Master student of educational administration, University of Sistan and Baluchestan, Zahedan, Iran \\ Correspondence: Naser Nastiezaie, Assistant professor of educational administration, University of Sistan and \\ Baluchestan, Zahedan, Iran. E-mail: n_nastie1354@ped.usb.ac.ir
}

Received: April 27, 2016

doi:10.5539/mas.v10n9p87

\begin{abstract}
The present study aimed to examine the relationship of servant leadership with trust and organizational efficacy. This descriptive study followed a correlational design. Using stratified random sampling method, 225 employees of Zahedan Department of Education were studied through applying three questionnaires on servant leadership, organizational trust, and organizational efficacy. To analyze the obtained data, Pearson correlation coefficient and simultaneous regression analysis were used via SPSS v.21. According to the results, the correlation coefficients between servant leadership and components of service, humility, trust, and agape love and organizational trust were respectively $0.758,0.646,0.664,0.698$, and $0.686(\mathrm{P}<0.01)$. Moreover, the results of multiple regression analysis revealed that agape love with a beta-value $(\beta)$ of 0.332 , service with a beta-value of 0.247 , and humility with a beta-value of 0.227 had the highest power to predict organizational trust. Additionally, the correlation coefficients between servant leadership and components of service, humility, trust, and agape love and organizational efficacy were respectively $0.66,0.533,0.518,0.68$, and $0.625(\mathrm{P}<0.01)$. The results of multiple regression analysis indicated that trust with a beta-value $(\beta)$ of 0.684 and service with a beta-value of 0.147 had the highest power to predict organizational efficacy. Therefore, it can be concluded that the more and the better managers of the Department of Education apply the servant leadership style, such that they demonstrate more service, humility, and agape love in their behaviors, actions, and leadership style, the more trust they gain, and the levels of organizational trust and organizational efficacy correspondingly increase.
\end{abstract}

Keywords: servant Leadership, organizational trust, organizational efficacy

\section{Introduction}

Various leadership models and theories has been proposed so far. Among these models, the servant leadership model is quite compatible with the current situation, can be a practical guide for managers and corporate leaders and can offer appropriate solutions to problems, including issues associated with trust and organizational efficacy, with which organizations face. In 1970, Greenleaf developed the model of servant leadership. He completely changed the traditional leadership models. This leadership theory is rooted in the moral teachings and relies on the methods people apply for interaction, motivation, and leadership. Using their leadership style and behaviors, required for creating and maintaining an effective and appropriate service system, these leaders determine their service standards. Indeed, these leaders not only consider themselves responsible for achieving corporate objectives and developing human resources, but also they feel obligated to stakeholders (Islami et al., 2012). Servant leadership is an approach to leadership and service wherein the leader is a servant first. Servant leadership is based on the philosophy of service and servant leaders are those who prioritize serving their followers, fulfilling their needs, and also developing and fostering their staff. Servant leaders prefer empowerment, mutual trust, spirit of cooperation, ethical use of power, and the value of providing service for the followers to anything else in the organization (Jinani, 2007).

Experts considered various components for servant leadership. Patterson (2003) proposed seven components including divine love, service, vision, trustworthiness, altruism, humility, and empowerment and Spears (1996) regarded ten components, including awareness, healing, listening, empathy, supervision, foresight, persuasion, conceptualization, building community, and commitment to growth, for servant leaders. Gholipour and Hazrati (2009) considered four components, i.e. service, trust, humility, and agape love, for servant leaders. In the 
current study, these four former mentioned components were regarded as components of servant leaders. A brief explanation was provided for these four components.

A. Service: Cardona believes that a good leader is a person who serves others so that they serve him and he shows serving others in his behaviors, attitudes and values. A leader who selects serving others provides required sources for other people's success and serves others through providing information, financial resources, time, attention and favor and the like which give meaning to other people's work.

B. Trust: Trust is a firm belief in one's reliability, trust, ability, and/or personality. Other words, trust is a group's passion and interest to another group's critical measures. Russell believes that trust is the essence of servant leadership. In addition, Melrose believes that leaders who act on what they say are those who create trust.

C. Humility: According to Sandage and Wiens, humility means that a person does not pay attention to himself/herself, but also he/she pays attention to others and considers their abilities and talents. Swindell noted that humility does not mean that a person does not respect himself/herself; however, it means that person does not consider himself/herself superior or inferior to others.

D. Agape Love: The basis of the relationship between a follower and a servant leader is founded on love. Winston believes that this love is a moral, social and spiritual concept. This affection aids leaders to not consider each person as a means to achieve their goals; however, it helps them to regard each person as a human being with human needs, wants, and desires (Gholipour \& Hazrati, 2009).

The basis of the servant leadership style and social relations, especially the relationships in organizations, is trust Brownell (2010, as cited in Dai et al., 2013) defined trust as a level of a person's trust to others' competence and to their ability to act fairly and ethically. According to Dennis (2004), trust is a multi-level concept that is concerned with the interactions among various levels of colleagues, teams, and different levels within an organization. In Taylor's opinion (2003, p. 556), trust is an important concept, since it has a strong desire to understand how people participate effectively within organizations. Boisot (1995) also put a great emphasis on the importance of trust between people in order to create knowledge in vague and ambiguous conditions. Trust has significant intrapersonal and interpersonal effects and also influences relationships within and outside an organization. In this regard, it is said that high organizational trust improves job satisfaction, organizational commitment, and an atmosphere of trust between employees, increases cooperation and consultation, information sharing, problem solving, empowerment facilitation, the ability to change, learning, and organizational innovation, decreases psychological and mental pressure, uncertainty about the future, conflict resolution, and finally creates a framework for increasing organizational efficacy in communication. On the other hand, low organizational trust typically increases conflicts, organizational instability, turnover, rumors and unresolved strikes, and obstacles to achieve organizational goals and reduces motivation and the like (Korsgard et al., 2002). Low levels of trust lead staff to divert the flow of information within the organization, spread suspicion and distrust among employees, wipe out open and honest communications within the organization, and direct organizational decisions towards an unfavorable path (Gholipour et al., 2009).

Given the importance of human resources in organizations and its role in the development and realization of organizational goals, paying attention to human resources efficacy is among the main concerns of today's managers. The significance of efficacy in the chain of an organization's value is to the extent that, nowadays, it is considered as the most effective indicator used to determine organizational success and competitive advantage. In many countries, major developmental plans are regarded based on the increase in efficacy, such that in the last fifteen years, the level of efficacy has increased 45 times all around the world (Faraji, 2006). According to the applied sources, efficacy refers to the level of quantity and quality of labor productivity. Efficacy is a point of view that always attempts to improve what already exists. In fact, efficacy is based on a belief that man can always accomplish his tasks and responsibilities better than before (Latifian \& Doaee, 2013). The main reason that mainly leads to the failure of an organization in achieving its goals is lack of human resources efficacy (Enshassi et al., 2007). Among the most important factors affecting employees' efficacy the following can be mentioned: employees' skills, employees' participation in decision-making, manager's support, continuous feedback, stipulated duties, continuous staff justification by the manager, paying attention to the work environment (Janalinejad, 2001), acquiring new skills, raising the level of training, providing a suitable suggestion system, maintaining physical health of staff, entrusting the work to others, appointing people to appropriate jobs, creating a good working condition and healthy recreational activities, managing the relationships between the manager and the staff (Rasoulimoghaddam, 2008), reforming employment systems and organizational structures, job enrichment, planning the required educational programs, delegating authority to 
middle level managers and administrators to decide, implementing incentive programs (Allahverdi et al., 2009), organizational culture (Wright et al., 2008), and the leadership style (Khaefellahi et al., 2007; Bordbar, 2012; Latifi et al., 2013).

Servant leadership is a style of leadership through applying which leaders pay more attention to their subordinates and clients. This is completely in accordance with the current organizational condition. Such a leader considers both organizational and personal consequences. In the present study, trust was considered as a personal consequence and efficacy was considered as an organizational consequence. Without a shadow of doubt, creating trust is the main element of any system, is the basis of its legitimacy, and its distortion in the long term will undermine the foundation of any system, such that major mistakes of political leaders related to citizens and lack of attention to serving them damage public trust and lead to a decrease in the legitimacy of the political system. Since building trust in an executive organization requires building trust between employees and managers of its various executive departments, paying attention to building trust within an organization seems necessary. To manage an organization optimally, building trust within the organization, as one of the most important social capital, is needed. This leads to create empathy between employees and managers of executive departments. On the other hand, all organizations look for more efficacy. To this end, they follow several mechanisms among which is a relatively new approach, i.e. the application of the servant leadership style. When investigating the literature review, it was revealed that less attention has been paid to examining the simultaneous relationship of servant leadership with trust and organizational efficacy. No similar studies has been conducted in Zahedan Department of Education; hence, this is a relatively new study. Moreover, any service organization should pay special attention to this issue. Therefore, the current study, both in terms of developing academic literature and practical applications is of significant importance. In this regard, examining the relationship of servant leadership with trust and organizational efficacy among employees of Department of Education seems essential. Moreover, identifying that which components of servant leadership lead to the formation of trust and organizational efficacy and which components could block them aids authorities of Zahedan Department of Education to develop appropriate programs.

Governmental organizations are usually established to implement their legal obligations, achieve the objectives of the government, implement approved programs, and provide services for people. Due to the fact that the scope of government activities is broaden and public expenditure is increased, considering the global economic and political conditions, paying attention to governmental organizations has become more important than before. Therefore, attempts to increase governmental organizations' efficacy seems essential. If managers of the governmental organizations be able to create a condition in which they can use the actual potentials of their employees, they can obviously improve their organization's efficacy. Moreover, to accomplish their duties and assigned activities, managers should be trusted by their employees. This is while the level of trust in Iranian governmental organizations is very low. Therefore, the decline in the level of trust in governmental organizations is among the issues that made employees motiveless and indifferent and lead to slow implementation of programs (Gholipour \& Hazrati, 2009). Given the indifference of government employees and lack of trust in governmental organizations and since building trust is greatly emphasized as an effective feature of servant leadership, it seems that the development of servant leadership can be a good solution to increase trust and organizational efficacy. Zahedan Department of Education, as a governmental organization, needs to increase organizational trust and efficacy and to use the servant leadership style. Since no similar studies has been conducted in this organization, the researcher was encouraged to carry out a study in order to present results and suggestions to authorities of Zahedan Department of Education. Therefore, the main research question was whether the servant leadership style is related to trust and organizational efficacy among employees of Zahedan Department of Education.

\section{Research Hypothesis}

1. Servant leadership and its components (service, humility, trust, and agape love) are related to organizational trust.

2. Components of servant leadership can predict organizational trust.

3. Servant leadership and its components (service, humility, trust, and agape love) are related to organizational efficacy.

4. Components of servant leadership can predict organizational efficacy.

\section{Methods}

The method of this study was descriptive-correlational (regression). The statistical population included all 
employees of Zahedan Department of Education in the academic year 2015-2016 whom were 544 individuals. Using stratified random sampling method and considering the sample size and the result of Cochran's sample determination formula, 225 individuals were studied. To collect data, three questionnaires were applied.

A. The Gholipour and Hazrati Servant Leadership Inventory (2009): This scale examines the servant leadership style in terms of 4 components and 28 items: Service (items 1-6), humility (items 7-13), trust (items 14-23), and agape love (items 24-28). This inventory is developed based on a 5-point Likert type scale (ranging from $1=$ strongly disagree to $5=$ strongly agree). In this inventory, the minimum score is 1 and the maximum score is 5 . Closer test scores to 5 indicate better and more appropriate use of the servant leadership style in an organization.

B. Organizational Trust Questionnaire (Kanavatachay \& Yu, 2002): This 12-item questionnaire was developed to measure organizational trust. This questionnaire was designed based on 5-point Likert type scale (ranging from $1=$ strongly disagree to $5=$ strongly agree). The higher scores indicate the spread of trust in an organization and vice versa.

C. Organizational Efficacy Scale (Saatchi, 2010): This scale investigates the organizational efficacy and it contains 15 items. This scale was designed based on a three-point Likert type scale (agree, no idea, disagree). This scale is scored as follows: If a respondent chooses agree for questions number $1,3,5,7,8$, 10, 12, and 14, he/she receives 2 points for each answer. However, if a respondent chooses disagree for questions number $2,4,6,11,13$, and 15 , he/she receives 1 point for each answer. "No idea" receives no such points. If the obtained score is between 20 and 30, the respondent probably works in an organization, the efficacy of which is desirable. However, if the obtained score is between 10 and 20, the respondent probably works in an organization, the efficacy of which is undesirable and if the obtained score is between 5 and 10 , the respondent probably works in an organization, the efficacy of which is very low. To determine the validity of these questionnaires, content validity was used. In this regard, these questionnaires were confirmed by faculty members of management department in University of Sistan and Baluchestan and it was assured that these questionnaires measure the considered variables and are valid. To examine the reliability of these questionnaires, Cronbach's alpha coefficient was applied, the results of which related to the Servant Leadership Inventory, Organizational Trust Questionnaire, and Organizational Efficacy Scale were respectively $0.79,0.86$, and 0.77 . These coefficients indicate that the applied questionnaires have desirable reliabilities. To analyze the obtained data, Pearson correlation coefficient and simultaneous regression analysis were used via SPSS v.21.

\section{Results}

First Hypothesis: Servant leadership and its components (service, humility, trust, and agape love) are related to organizational trust. Cross-correlation coefficients between the variables related to this hypothesis are presented in Table 1.

Table 1. Correlation coefficients of servant leadership (and its components) with organizational trust

\begin{tabular}{lll}
\hline \multicolumn{3}{c}{ Organizational Trust } \\
\hline Variable & $\mathrm{R}$ & $\mathrm{Sig}$ \\
\hline Service & 0.646 & 0.000 \\
Humility & 0.664 & 0.000 \\
Trust & 0.698 & 0.000 \\
Agape love & 0.686 & 0.000 \\
Servant leadership & 0.758 & 0.000 \\
\hline
\end{tabular}

The results presented in Table 1 indicate that the correlation coefficients between servant leadership and all its components and organizational trust are positive and significant $(\mathrm{P}<0.01)$; therefore, the existence of a positive and significant relationship between servant leadership and organizational trust is confirmed. This means that the more and the better a manager applies servant leadership, the more the organizational trust increases.

Second Hypothesis: Components of servant leadership can predict organizational trust. To test this hypothesis, simultaneous multivariate regression analysis was applied, the results of which are presented in Table 2. 
Table 2. The results

\begin{tabular}{llllll}
\hline & \multicolumn{2}{l}{ Non-standardized coefficients } & Standardized coefficients & T & \multirow{2}{*}{ Sig } \\
\cline { 2 - 4 } & $\mathbf{B}$ & Std. Error & Beta & & \\
\hline Constant & 0.489 & 0.204 & & 2.4 & 0.017 \\
Service & 0.228 & 0.06 & 0.247 & 3.77 & 0.000 \\
Humility & 0.202 & 0.063 & 0.227 & 3.21 & 0.001 \\
Agape & 0.353 & 0.137 & 0.332 & 2.57 & 0.011 \\
love & & & & & \\
\hline Sig $=\mathbf{0 . 0 0 0 ,} \mathbf{F}=\mathbf{7 4 . 9 5 6}$, Adjusted $\mathbf{R}^{\mathbf{2}}=\mathbf{0 . 5 7 7}, \mathbf{r}=\mathbf{0 . 7 5 9}$ &
\end{tabular}

Based on the results presented in Table 2, the amount of multiple correlation coefficient (r) is 0.759 and Adjusted $\mathrm{R}^{2}$ is 0.577 , i.e. $\% 57.7$ of the variance in the criterion variable (organizational trust) can be explained by the entered predictor variables. Among components of servant leadership, respectively, agape love with a beta-value of 0.332 , service with a beta-value of 0.274 , and humility with a beta-value of 0.227 have the highest power to predict organizational trust.

Third Hypothesis: Servant leadership and its components (service, humility, trust, and agape love) are related to organizational efficacy. Cross-correlation coefficients between the variables related to this hypothesis are presented in Table 3.

Table 3. Correlation coefficients of servant leadership (and its components) with organizational efficacy

\begin{tabular}{lcl}
\hline & Organizational Efficacy & \\
\hline Variable & $\mathrm{R}$ & Sig \\
Service & 0.533 & 0.000 \\
Humility & 0.518 & 0.000 \\
Trust & 0.68 & 0.000 \\
Agape love & 0.625 & 0.000 \\
Servant leadership & 0.66 & 0.000 \\
\hline
\end{tabular}

The results presented in Table 3 indicate that all correlation coefficients between servant leadership and its components and organizational efficacy are positive and significant $(\mathrm{P}<0.01)$; therefore, the existence of a positive and significant relationship between servant leadership and organizational efficacy is confirmed. This means that the more and the better a manager applies servant leadership, the more the organizational efficacy increases.

Fourth Hypothesis: Components of servant leadership can predict organizational efficacy. To test this hypothesis, simultaneous multivariate regression analysis was applied, the results of which are presented in Table 4 .

Table 4 . The results

\begin{tabular}{llllll}
\hline & \multicolumn{2}{l}{ Non-standardized coefficients } & Standardized coefficients & T & \multirow{2}{*}{ Sig } \\
\cline { 2 - 4 } & $\mathbf{B}$ & Std. Error & Beta & & \\
\hline Constant & 0.405 & 0.108 & & 3.75 & 0.000 \\
\hline Service & 0.065 & 0.032 & 0.147 & 2.02 & 0.044 \\
\hline Trust & 0.316 & 0.073 & 0.684 & 4.31 & 0.000 \\
\hline Sig $=\mathbf{0 . 0 0 0}, \mathbf{F}=\mathbf{4 9 . 7 0 1}$, Adjusted $\mathbf{R}^{\mathbf{2}}=\mathbf{0 . 4 7 5}, \mathbf{r}=\mathbf{0 . 6 8 9}$ & & \\
\hline
\end{tabular}

Based on the results presented in Table 4, the amount of multiple correlation coefficient (r) is 0.689 and Adjusted $\mathrm{R}^{2}$ is 0.475 , i.e. $\% 47.5$ of the variance in the criterion variable (organizational efficacy) can be explained by the entered predictor variables. Among components of servant leadership, respectively, trust with a beta-value of 0.684 and service with a beta-value of 0.147 have the highest power to predict organizational efficacy. 


\section{Discussion and Conclusion}

The results obtained from this study indicated that servant leadership style and its components were correlated with organizational trust. Moreover, agape love, service, and humility were able to predict organizational trust. To explain these results, it can be mentioned that the more managers use the servant leadership style, such that they demonstrate more service, humility, and agape love in their behaviors, actions, and leadership style, the more trust they gain, and the level of organizational trust correspondingly increases. This finding (the relationship between servant leadership and organizational trust) is in line with the results obtained from previously conducted studies. Rezaei et al. (2012) found that servant leadership can be significantly and positively related to organizational trust. Additionally, the results revealed that there were significant and positive relationships between servant leadership and organizational trust and between a manager's ability to trust and organizational commitment. A study carried out by Sendjaya and Pekerti (2010) demonstrated that servant leadership was strongly related to trust. They concluded that a servant leader plays a key role in creating the culture of trust. Trust exists in an organization in which managers act as they say (credit) and behave in a predictable way (stability). Russell and Stewen (2002), in a study, indicated that building trust is one of the most significant aspects of the servant leadership, since paying attention to others and to the followers' interests, as key and essential elements of servant leadership, lead followers to trust the leader. In another study, Ostori (2002), besides expressing a positive and significant relationship between servant leadership and trust, stated that trust is a key feature of servant leadership. Through guiding, empowering, and encouraging others, servant leaders model honesty and integrity in the organization. Other findings of this study revealed that servant leadership style and its components were correlated with organizational efficacy. Moreover, trust and service were able to predict organizational efficacy. This finding (the relationship between servant leadership and organizational efficacy) is consistent with the results obtained from previously conducted studies. As an instance, Nathan (2014) conducted a study entitled "The Effect of the Servant Leadership Style on Work Engagement and Workplace Efficacy" and found that servant leadership was significantly and positively related to work engagement and organizational efficacy among employees. This means that with an increase in applying the components of the servant leadership style, employees' work engagement and the workplace efficacy increase significantly. Mahembe and Engelbrecht (2013), in a study aimed to examine the role of the servant leadership style and emotional commitment on team effectiveness among elementary and high school teachers in Africa, concluded that both the leadership style and emotional commitment can predict team effectiveness. Moreover, the results demonstrated that if a servant leader applies emotional commitment, he/she may achieve team effectiveness much faster. Sakiru et al. (2013), in a study conducted in Nigeria aimed to examine the relationship between leadership and employees' efficacy, found that leadership style was significantly and positively correlated with employees' efficacy. Melchar and Bosco (2010) carried out a study in for-profit organizations which provide various services for customers and introduced the servant leadership model as a key to define today's economy successfully.

Overall, it can be said that servant leaders are not exclusive because of their own leadership style, but the way they view the world around them distinguishes these leaders from other leaders. Accordingly, leaders' and managers' positive viewpoints to serve others can be fostered and used in the organization. Since only self-report questionnaires were used to evaluate the variables under study and given the fact that the sample of this study only included employees of Zahedan Department of Education, there are limitations in generalizing these results to other employees and organizations. Given the positive and significant relationship of the servant leadership style with trust and organizational efficacy, managers of Department of Education are highly recommended to:

- Show serving others in their behaviors, attitudes, and values and have a sense of responsibility.

- Show their humility and respect towards their followers through participating them in the decision-making process.

- Create a good environment through applying benevolence, competence, honesty, truthfulness, and openness in mutual relations and prevent any kinds of backbiting and secrecy in the workplace. These lead to create an organization with a trusted environment and high reliability.

- Not consider other people as a means to achieve their goals and regard them as human beings with their own needs, wants, and desires. This indicates managers' devotion to the staff.

\section{References}

Allahverdi, M., Farahabadi, E., \& Sajadi, H. (2011). Prioritizing factors effecting on human resources productivity: Viewing of middle class managers in Isfahan University of Medical Sciences 2009. J Hosp, 9 
(3-4), 77-85.

Boisot, M. (1995). Information Space, A Framework for Learning in Organizations, Institutions and Culture. London.

Bordbar, G. (2013). The Effective Factors on Labor Productivity with Multi-criteria Decision Making Techniques, A Case Study: Personnel of Shahid Sadoghi Hospital in Yazd. Journal of Health Administration, $16(51), 70-83$.

Dai, Y. D., Dai, Y. Y., Chen, K. Y., \& Wu, H. C. (2013). Transformational vs. transactional leadership, which is better? A study on employees of international tourist hotels in Taipei City. International Journal of Contemporary Hospitality Management, 25(5), 760-78.

Dennis, R. S., (2004). Servant Leadership Theory, Assessment Instrument. A Dissertation presented in Partial fulfillment of the requirement for the degree Doctor of Philosophy.

EnShassi, A., Mohammed, S., Mayer, P., \& Abed, K. (2007). Benchmarking Masonry Labor Productivity, International J Productivity and Performance Management, 56(4), 358-368.

Eslami, Y., \& Jajly, H. (2012). Study of Structural Relationships between Organizational Service Orientation, Contact employee Job Satisfaction and Citizenship Behavior (Case Study: Mellat' Bank Branches in Tehran). Management Research in Iran, 16(1), 53-72.

Faraji, H. (2006). Labor productivity in organizations. The National Conference on Productivity, Tehran, Iran.

Janalinejad (2001). Factors affecting employee productivity in Tarbiat Modarres University. Master's thesis, Tarbiat Modarres University of Tehran.

Jennine, L. P. (2007). Investigation the distinction between transformational and servant leadership. A Dissertation presented in Partial fulfillment of the requirement for the degree Doctor of Philosophy, Regent University.

Latifi, M., Pour, S., Hoseini, Z., \& Heidari, M. A. (2013). The impact of servant leadership on trust in teams and team effectiveness. Transformation Managemet Journal, 5(10), 65-93.

Latifiyan, A., \& Doayi, A. H. (2013). Designing Personnel Productive Conceptual Model by Interpretive Structural Approach (A case study of plan and program deputy section of ferdowsi university of mashhad). Management Researches, 6(20), 5-33.

Mahembe, B., \& Engelbrecht, A. E. (2013). The relationship between servant leadership, affective team commitment and team effectiveness. SA Journal of Human Resource Management/SA Tydskrif Vir Menslike Hulpbronbestuur, 11(1), 1-10.

Rasuli, M. O., \& Gdam, T. (2008). Knowledge management to increase labor productivity. The National Conference on Productivity, Tehran, Iran.

Rezaei, M., Salehi, S., Shafiei, M., \& Sabet, S. (2012). Servant Leadership and Organizational Trust: The Mediating Effect of the Leader Trust and Organizational Communication. Emerging Markets Journal, 2(2012), 70-80.

Russell, R., \& Stone, G. A. (2002). A review of servant leadership attributes: Developing a practical model. Leadership \& Organization Development Journal, 23(3), 145-157.

Sakiru, O. K., Othman, J., Yero, A., Abdullahi, M., \& Kia, N. (2013). Relationship between leadership and employee productivity in anorganization. IOSR Journal of Business and Management (IOSR-JBM), 9(4), 62-69.

Sendjaya, S., \& Pekerti, A. (2010). Servant leadership as antecedent of trust in organizations. Leadership \& Organization Development Journal, 31(7), 643-653.

Tyler, T. R. (2003). Trust within Organizations. Personnel Review, 32(5), 556-68.

\section{Copyrights}

Copyright for this article is retained by the author(s), with first publication rights granted to the journal.

This is an open-access article distributed under the terms and conditions of the Creative Commons Attribution license (http://creativecommons.org/licenses/by/3.0/). 